\title{
The Effect of Service Quality Dimensions on Students' Satisfaction in University of Medical Sciences and Technology (UMST) Hostel Accommodation (Sudan)
}

\author{
Khairi Mohamed Omar ${ }^{1} \&$ Ahmed Mohammed Arbab ${ }^{1}$ \\ 1 Business Administration Department, College of Administrative Sciences, Applied Science University, \\ Kingdom of Bahrain. \\ Correspondence: Khairi Mohamed Omar, Assistant Professor in Business Administration Department, College of \\ Administrative Sciences, Applied Science University, Kingdom of Bahrain. E-mail: khairi.omar@asu.edu.bh
}

Received: July 28, $2018 \quad$ Accepted: September 14, $2018 \quad$ Online Published: September 28, 2018

doi:10.5539/ass.v14n10p1 URL: https://doi.org/10.5539/ass.v14n10p1

\begin{abstract}
This paper aims to examine the effects of service quality dimensions on students' satisfaction in University of Medical Sciences and Technology (UMST) students' hostel accommodation in Sudan. It is based on an empirical study conducted at one of the Sudanese Private University. A quantitative method was employed. Out of 367, there were 200 questionnaires were returned represented 55\% of the study response rate. SPSS version 22 and AMOS version 21.0 were used in the analysis the collected data. The study proposed six direct effects. The results support two direct effects. Although the study conducted regarding the student's satisfaction in a Sudan education environment, the result of this study cannot be generalized.
\end{abstract}

Keywords: service quality dimensions, perceived value, students' satisfaction, hostel accommodation, University of Medical Sciences and Technology (UMST)

\section{Introduction:}

In the current competitive academic environment, where there is a verity of available options for the students, the factors that allow educational institutions to attract students must be studied seriously. The competitive advantage which all higher education institutions pursuing in the future, required a creative and effective means in order to retain, attract and foster stronger relations with students. Therefore, private organization, has to depend on the market interaction and the mechanism. As a result, the competition to encourage as many potential clients as possible can turn out to be more and more powerful.

It is normal for the private institution to depend on themselves in terms of financial support where they usually have no privilege to receive any types of government subsidies from the government (Teo, 2001). However, to give some insights into the real situation of the Higher Education Institutions, institutions must give a great deal of importance to meeting client expectations which are same with a business organization (Kanji, Abdul Malek, \& Wallace, 1999). However, these institutions still facing lots of customer awareness issues among their staff, which unfortunately it has turned out to be a common drawback for a verity of institutions.

This leads to understanding that students are more likely will have supplementary chances to support their continued enrollment in the higher education institutions and how well these programs offered by the institutions and services will meet students' expectations for services. To sum up, it is the satisfaction with services will always make the difference (Parasuraman, Zeithaml, \& Berry 1996). Which drew the importance of this study with its intention to explore the sides of the service quality and the satisfaction level of the private institutions' students of higher education.

\section{Research Problem}

With only five public universities and a limited number of students and no private universities the Sudan started the education sector in previous time. This has clearly imperfect the competing roles among the existed universities in attracting students. At present, there were more than 50 public and private universities and colleges operating in the country. Based on that, it resulted in a competitive academic environmental; where students have many options available to them; factors that enable educational institutions to attract and retain 
students should be seriously studied. Higher education providers, who want to gain competitive advantages, may need to begin looking for practical and creative ways to attract, retain and foster stronger relationships with students. In turn, this will give the students more opportunity to support their continued enrollment into higher education providers and on how well the educational programs and services met students' expectations for services. Some public and private higher education providers in Sudan have progressed in the application of Service Quality Dimensions where they have gained considerable benefits. This had led the researchers to reflect on the topic and to find an answer to the following central research question: "To what extent the mediating perceived value effects on Service Quality Dimensions namely "Tangibility, Reliability, Responsiveness, Assurance, and Empathy" and students' satisfaction relationship in UMST Hostel Accommodation?"

\section{The Significance of the Study}

The significance of the study stems from the importance of Service Quality Dimensions, Perceived Value and Students' Satisfaction in all Sudanese Universities Hostel Accommodation and UMST Hostel Accommodation in particular.

\section{Objectives of Study}

i. To know the effect of Service Quality Dimensions on Students' satisfaction in UMST Hostel Accommodation.

ii. To know the effect of Service Quality Dimensions on Students' Perceived Value in UMST Hostel Accommodation.

iii. To know the mediating effects of Perceived value between the Service Quality Dimensions and Students' Satisfaction in UMST Hostel Accommodation.

\section{Literature}

This section reviews the related literature:

\subsection{Student Satisfaction}

The satisfaction has been defined by several scholars as a case felt by an individual with experience performance or an outcome fulfill of a personal expectation (Kotler \& Clarke, 1987). It is normally a function of the comparative level of comprehend performance. Students even enter the higher education may go as far as before their expectation which left the door open for the researchers to determine first what the students expect before entering the university (Palacio, Meneses, \& Pérez, 2002). In contrary to Carey, Cambiano, \& DeVore, (2002) where they believe that satisfaction covers matters of students' perception and experiences throughout their studies years. While most research regarding student satisfaction focuses on the perspective of the client, a problem of producing a typical explanation for students satisfaction are facing most of the researchers thus providing a necessity of customer satisfaction theory to be selected and adapted so that it can explain the meaning of student satisfaction (Omar, Mat, \& Imhemed, 2102). Although it is dangerous to look at students as a client, given the current atmosphere of the higher education marketplace, there is a new moral privilege that the student has become a "clients" and thus, as fee payers, can reasonably ask for their views and act accordingly (William, 2002).

\subsection{Service Quality}

There are several definitions of quality, however, these definitions are revolves around the idea which is says quality should be a judged when evaluating or assessing a service provided to a consumer. The construction of quality as a conceptual is based on the literature of services on perceived quality. Recognized quality is defined as the judgment of the consumer on the experience or superiority of the entity in general (Zammuto et al., 1996; Zeithaml, 1987). Likewise, Zeithaml, and Berry (1990) reported that customer perceptions of quality of service as a result of comparing expectations before they receiving the service and testing service. According to Rowley, (1996), the perceived quality of any provided service is understood as a form of associated, but not the similar satisfaction that results of comparing expectations by means of performance perceptions. Thus, the perceived quality of service can be a product of assessments of some service meetings. In such case the students may range out from meetings with office staff to meetings with teachers and lecturers, heads of departments, etc. (Hill, 1995).

As a result, if an organization regularly provides a service beyond the client's expectations, the service will be considered high quality. On the contrary, if an organization does not meet the expectations of its client, it will be judged that the service is of poor quality (Zammuto et al., 1996).

Actually, based on the empirical evidence by Lassar, Manolis, and Winsor (2000) and Gronroos (1984), the most widespread two factors accepted perspectives on service quality include the service quality model and the 
Technical Quality framework held that service quality is made up of three dimensions" the technical quality of the outcome, functional quality of the encounter and the company corporate image".

There is a great debate regarding to the examining of the determinants of quality, of course it is needed to differentiate between quality associated with the process of service delivery and quality associated with the outcome of service, judged by the consumer after the service is performed. There are a ten determinants of service quality which have been listed by Parasuraman, Zeithaml, and Berry (1985), these ten determinants can be generalized to a verity of services, which is included "tangibility, reliability, responsiveness, competence, access, courtesy, communication, credibility, security and understanding". Absolutely, these ten determinants were then reformed in the famous five aspects "assurance, empathy, reliability, responsiveness, and tangibility" in the SERVQUAL model (Parasuraman et al., 1990). However, the complexity of tangibility, empathy, reliability, responsiveness, and assurance can increase consumer satisfaction towards the services rendered by the organization human resource department (Omar, 2016).

In general, there are three basic criteria that need to be satisfied for the students need (Requisite encounters, acceptable encounters and functional, an encounter of a practical or utilitarian nature. Oldfield and Barron (2000) reported that, these criteria are described as necessary meetings that enable students to meet their study obligations; acceptable interviews are recognized by students as desirable but not necessary during their studies. According to Lassar, Manolis and Winsor (2000), the two most widely accepted and widely accepted perspectives on quality of service include the service quality model and the functional quality framework.

Gronroos (1984) reported that the quality of service involves of three dimensions: "Professional Quality of the Result", "Functional Quality of Meeting" and "Company Image Company". This has been argued in the context of the study of quality determinants, which is essential to distinguish between the quality related to the delivered service process and the quality related with the results of the service, which the consumer assesses after being serviced. Nevertheless, Parasuraman, Zeithaml, and Berry (1985), have comprised more than nine service quality elements which can be widespread to any deal. They include ten dimensions of concrete, reliability, responsiveness, efficiency, access, courtesy, communication, credibility, security and understanding. These ten dimensions have also been reassembled in the five well-known aspects of the SERVQUAL model (Parasuraman et al., 1990), which include affirmation, empathy, reliability, responsiveness and appropriateness. However, the complexity of reliability, empathy and concrete.

\section{Method of the Study}

Based on reviewing the related literature and the current study objectives, conceptual framework has been formulated as shown in Figure 1.

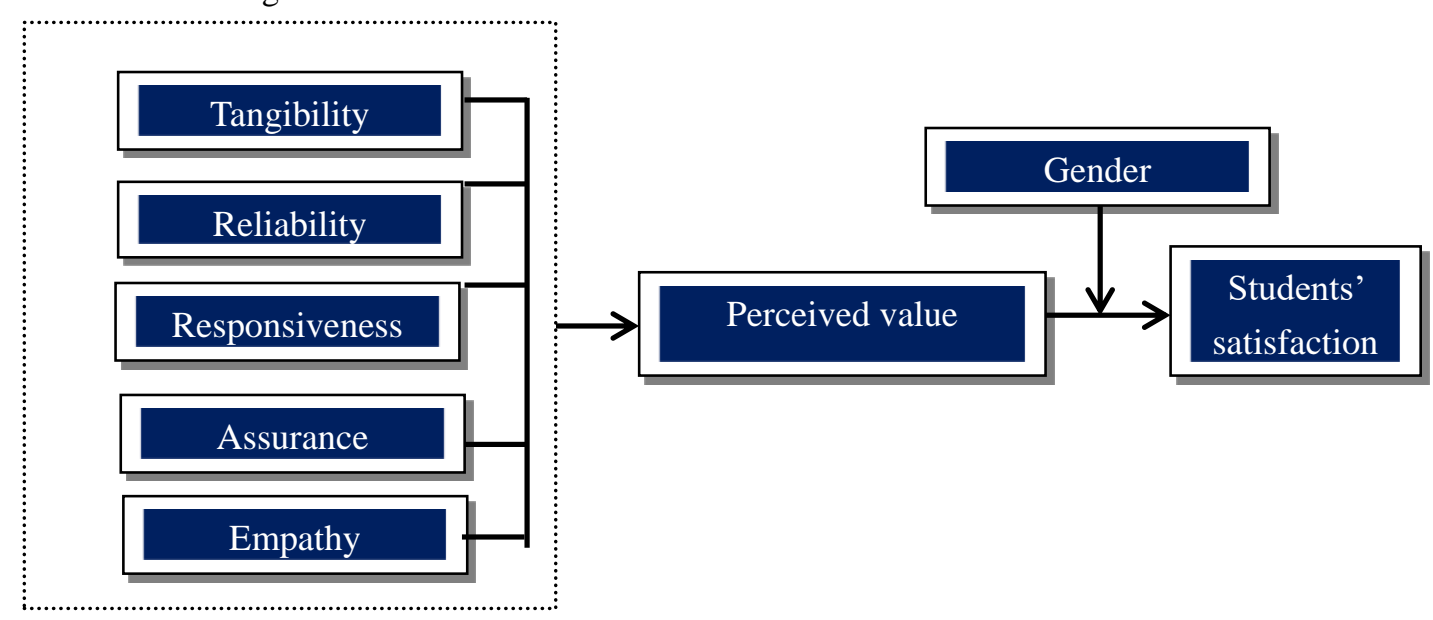

Figure 1. Conceptual framework

From the conceptual framework, it can be seen that SERVQUAL dimensions are directly predictors of perceived value. The perceived value is presented as direct predictor of students' satisfaction.

The establishing variables of this proposed conceptual framework are drawn using the error terms individually for each latent variable in the way to explain and interpret into the hypothesized model. Hence, the exogenous variables of the SERVQUAL dimensions, each contain four to six showing (observed items) variables correspondingly. 
Therefore, an error for each piece is drawn as un-observed variables in circles and labeled e01 to e25. Where, the perceived value and students' satisfaction, as an endogenous latent variable the manifesting variables are five for each variable. The subsequent error terms are labeled e26 to e34 as in the diagram. However, a different error (R35 and R36) for each endogenous variable are attached by e as displayed in Figure 2.

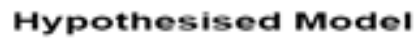

Standardized estimates Chi-Square: 747.538

Df : 512

Ratio: 1.460

P-value : :OOO

GFI::823

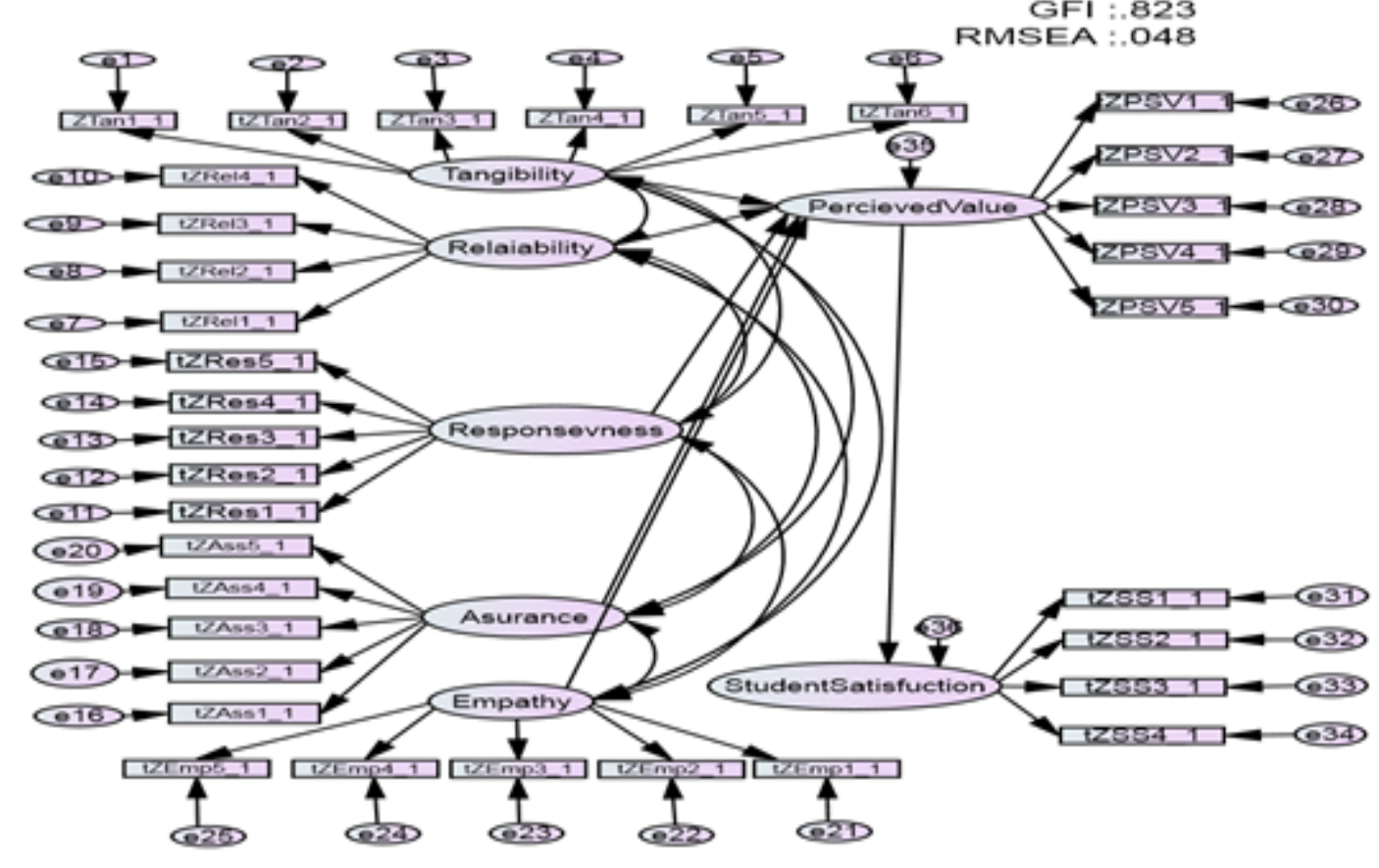

Figure 2. Hypothesized model

\section{Research Hypotheses}

Based on the conceptual framework, the hypothesized model and reviewing of the related studies and theories, the study hypotheses were formulated as below:

Hypothesis 1: Tangibility is the direct predictor of perceived values in UMST Hostel Accommodation.

Hypothesis 2: Reliability is the direct predictor of perceived values in UMST Hostel Accommodation.

Hypothesis 3: Responsiveness is the direct predictor of perceived values in UMST Hostel Accommodation.

Hypothesis 4: Assurance is the direct predictor of perceived values in UMST Hostel Accommodation.

Hypothesis 5: Empathy is the direct predictor of perceived values in UMST Hostel Accommodation.

Hypothesis 6: Perceived values are the direct predictor of students' satisfaction with UMST Hostel Accommodation.

Hypothesis 7: Perceived values mediate the relationship between tangibility and students' satisfaction with UMST Hostel Accommodation.

Hypothesis 8: Perceived values mediate the relationship between reliability and students' satisfaction with UMST Hostel Accommodation.

Hypothesis 9: Perceived values mediate the relationship between responsiveness and students' satisfaction with UMST Hostel Accommodation.

Hypothesis 10: Perceived values mediate the relationship between assurance and students' satisfaction with UMST Hostel Accommodation.

Hypothesis 11: Perceived values mediate the relationship between empathy and students' satisfaction with UMST Hostel Accommodation. 


\section{Study Target Population, Sampling and Instrument}

According to the university admission and registration department there are around 8000 students studying in UMST. For the aim of this research, the 370 is considered as the target population (Krejcie \& Morgan, 1970; Sekaran, 1992 \& 2003, p, 278). Based on Hair, (2010), table for determining a sample size from population. A random sample of 370 students in were invited to complete a questionnaire that contained measures of the constructs of the study's concern. Using purposive sampling method the questionnaires were distributed to the targeted respondents in UMST campus. A 55\% as response rate was collected back which corresponding to 200 distributed questionnaire.

Each variable were measured by using 7 -point interval-scale as $1=$ strongly disagree, to $7=$ strongly agree.

There are also seven demographic questions included in the instrument, which use ordinary and nominal scales such as gender, age, country, education, and marital status, duration living in hostel or room and roommates per hostel or room.

\section{Data Screening and Analysis}

The 200 dataset were coded and saved into SPSS version 19 and analyzed using AMOS version 7.0. There was no missing data. During the process of data screening for outliers, there was no dataset to delete due to Mahalanobis $\left(\mathrm{D}^{2}\right)$ values not more than the $\chi^{2}$ value $\left(\chi^{2}=67.99 ; n=36, \mathrm{p}<.005\right)$.

For the purpose of checking the normality of the distributed data, the univariate normality computations were conducted using z-scores of Skewness statistics and standard error of Skewness as well as kurtosis statistics (Jr, Black, Babin, \& Anderson, 2006).

\section{Results}

This section will report the result of the paper as following:

\subsection{The Profile Demographic of Respondents}

Based on the study results, it appeared that respondents' in terms of ages were ranged from 17 to 27 years old showing an average of 22 years old. The female represented 69\%, where the male respondents were $31 \%$. Regarding the respondents qualification, it was varies from bachelor's degree with $76 \%$, where, respondents with diploma degree represented 24\%. The major respondent's rate was Sudanese with $84 \%$, other Arabic nationalities $11 \%$, where the lowest percentage response rate were Africans students with 5\%. The Marital status of the single was the highest with $93 \%$ and for married was only $7 \%$. Furthermore, roommates living average in one room are funded to be one $15 \%$, two $30 \%$, three $50 \%$, and no roommates are $5 \%$. However, the results show an average duration with less than one year $6 \%$, one to three years $14 \%$, four to six years $75 \%$, and more than six years $5 \%$.

\subsection{Variables Descriptive Analysis}

The conceptual framework of this study consists of seven variables "five exogenous and two endogenous" each one of these constructs showed acceptable values of Cronbach's Alpha readings "above 0.6" (Nunnally, 1970). The Composite reliability as well showed a similar high reading as it displayed in Table 1.

Table 1. Descriptive statistics of variables

\begin{tabular}{ccccc}
\hline $\begin{array}{c}\text { Variable } \\
\text { Name }\end{array}$ & $\begin{array}{c}\text { No. of } \\
\text { Items }\end{array}$ & $\begin{array}{c}\text { Mean } \\
(\text { Std. Dev })\end{array}$ & $\begin{array}{c}\text { Cronbach } \\
\text { Alpha }\end{array}$ & $\begin{array}{c}\text { Composite } \\
\text { Reliability }\end{array}$ \\
\hline Tangibility & 6 & $2.55(0.943)$ & 0.623 & 0.931 \\
Reliability & 4 & $1.60(0.666)$ & 0.770 & 0.937 \\
Responsiveness & 5 & $2.520(0.437)$ & 0.613 & 0.835 \\
Assurance & 5 & $1.601(0.625)$ & 0.715 & 0.931 \\
Empathy & 5 & $1.510(0.686)$ & 0.787 & 0.966 \\
Perceived service & 5 & $1.538(0.705)$ & 0.753 & 0.837 \\
Students satisfaction & 5 & $1.598(0.744)$ & 0.605 & 0.920 \\
Total Items & 35 & & & \\
\hline
\end{tabular}




\subsection{Convergent Validity (Confirmatory Factor Analysis-CFA)}

Out of the confirmatory factor analysis (CFA) outcomes, it observed that the regression estimates (the factor loadings of all manifesting observed variables or items) are satisfactory ranging from (0.507) to (0.938). However, factor loadings of the latent variables to an observed should be over (0.50) (Hair et al., 2006). Therefore, the generated results indicate that all the constructs conform to construct convergent validity test.

\subsection{Discriminant Validity}

According to Fornell and Larcker (1981) for the substantiating of the discriminant validity, Average Variance Extracted must be associated to correlation squared of the interrelated variables of concerned as it is displayed in below tables (Table 2 and 3).

Table 2. Squared multiple correlation results

\begin{tabular}{cc}
\hline Endogenous Variable & Squared Multiple Correlation $(\mathrm{SMC})=\mathrm{R}^{2}$ \\
\hline Perceived value & $5.4 \%$ \\
Students satisfaction & $75.8 \%$ \\
\hline
\end{tabular}

After the variance extracted, AVE calculated by averaging the two variances extracted from the variables. The results are displayed in a below Table 3.

Table 3. Average Variance Extracted (AVE) matrix of variables

\begin{tabular}{ccccccc}
\hline Variable Name & 2 & 3 & 4 & 5 & 6 & 7 \\
\hline Tangibility (1) & & & & & & \\
Reliability (2) & 1 & & & & & \\
Responsiveness (3) & 0.91 & 1 & & & & \\
Assurance (4) & 0.99 & 0.91 & 1 & & & \\
Empathy (5) & 0.99 & 0.9 & 0.99 & 1 & & \\
Perceived service (6) & 0.98 & 0.91 & 0.99 & 0.99 & 1 \\
Students satisfaction (7) & 0.99 & 0.92 & 0.98 & 0.98 & 0.98 & 1 \\
\hline
\end{tabular}

For the discriminant validity to be supported, AVE value must be greater than the correlation squared as shown in Table 4 below. For instance, amongst the variables Tangibility and Reliability, the AVE $=0.910$ as shown in Table 3, while correlation squared $=0.025$ as shown in Table 4 below. Hence, AVE $>$ correlation squared, or Tangibility discriminates from Reliability. Thus, discriminant validity is supported. All constructs used for this study support discriminant validity.

Table 4. Correlation square matrix among variables

\begin{tabular}{ccccccc}
\hline Variable Name & 1 & 2 & 3 & 4 & 5 & 6 \\
\hline Tangibility (1) & 1 & & & & & \\
Reliability (2) & $0.025^{* *}$ & 1 & & & & \\
Responsiveness(3) & $0.074 * *$ & $1.016^{* *}$ & 1 & & & \\
Assurance (4) & $-0.126^{* *}$ & $0.206^{* *}$ & $-0.179^{* *}$ & 1 & & \\
Empathy (5) & $0.017^{*}$ & $0.311^{* *}$ & $0.494 * *$ & $0.619 * *$ & 1 & \\
Perceived service (6) & -0.024 & $-0.013 * *$ & $0.413^{* * *}$ & $0.171^{* *}$ & $-0.173^{* *}$ & 1 \\
Students satisfaction (7) & $0.569^{* *}$ & $0.585^{* * *}$ & $0.494 * *$ & $0.461 * *$ & $0.394 * *$ & $0.83^{* *}$ \\
\hline
\end{tabular}

Significance Level: $*=.05, * *=.01, * * *=.001$

Note: Values below the diagonal are correlation estimates among constructs, diagonal elements are constructed variances, and values above the diagonal are squared correlation. Since all correlations are significant, mediation is plausible. 
Nomological validity looks into the correlations between constructs in the measurement theory whether makes sense such that correlations necessity be positive or negative according to theory specified (Hair et al., 2006). All directions of correlations are in the hypothesized direction as stipulated in the hypotheses in accordance with the theory as it shows in Table 5. Thus, it can be say that nomological validity is substantiated for all measures used in this study.

\subsection{Goodness of Fit of Structural Model}

The confirmatory factor analysis (CFA) were conducted on every construct and measurement models in order to arrive at the final structural model (Table 5 and Table 6).

Table 5. Goodness of Fit Analysis-Confirmatory Factor Analysis (CFA) of Models (N=198)

\begin{tabular}{cccccccc}
\hline $\begin{array}{c}\text { Finals } \\
\text { Models }\end{array}$ & Tangibility & Reliability & Responsiveness & Assurance & Empathy & $\begin{array}{c}\text { Perceived } \\
\text { service }\end{array}$ & $\begin{array}{c}\text { Students } \\
\text { satisfaction }\end{array}$ \\
\hline $\begin{array}{c}\text { Original } \\
\text { Items }\end{array}$ & 6 & 4 & 5 & 5 & 5 & 5 & 5 \\
Items & 5 & 3 & 5 & 3 & 3 & 3 & 3 \\
remain & & & & & & & \\
CMIN & 4.936 & 4.514 & 2.547 & 5.788 & 2.379 & 3.373 & 10.003 \\
Df & 5 & 2 & 5 & 2 & 2 & 2 & 5 \\
CMIN/df & 0.987 & 2.257 & 0.509 & 2.894 & 1.1901 & 1.687 & 2.001 \\
p-value & 0.424 & 0.105 & 0.769 & 0.055 & 0.304 & 0.185 & 0.075 \\
GFI & 0.99 & 0.989 & 0.995 & 0.986 & 0.994 & 0.991 & 0.891 \\
RMSEA & 0.066 & 0.08 & 0.099 & 0.098 & 0.031 & 0.059 & 0.071 \\
\hline
\end{tabular}

Table 6. Goodness of Fit Analysis-Confirmatory Factor Analysis (CFA) of Models (N=198)

\begin{tabular}{ccccc}
\hline Finals Models & $\begin{array}{c}\text { Exogenous: (Tangibility, } \\
\text { Reliability, Responsiveness, } \\
\text { Assurance \& Empathy) }\end{array}$ & $\begin{array}{c}\text { Endogenous (Perceived } \\
\text { service \& Students } \\
\text { satisfaction) }\end{array}$ & $\begin{array}{c}\text { Hypothesized } \\
\text { Model }\end{array}$ & $\begin{array}{c}\text { Revised } \\
\text { Model }\end{array}$ \\
\hline Original Items & 25 & 10 & 35 & 25 \\
Items remain & 19 & 6 & 35 & 25 \\
CMIN & 148.2 & 14.682 & 747.538 & 260.59 \\
Df & 142 & 8 & 512 & 259 \\
CMIN/df & 1.044 & 1.835 & 1.46 & 1.006 \\
p-value & 0.344 & 0.066 & 0 & 0.461 \\
GFI & 0.927 & 0.977 & 0.823 & 0.903 \\
RMSEA & 0.015 & 0.065 & 0.048 & 0.006 \\
\hline
\end{tabular}

According to Bagozzi \& Yi (1988), goodness of fit helps to see the model fits into the variance-covariance matrix of the dataset which accordingly will enable the researcher to take the decision. All Confirmatory Factor Analysis (CFAs) of constructs displayed produced a good fit as showed by the goodness of fit which indices such as CMIN/df ratio $(<2)$; p-value $(>0.05)$; Goodness of Fit Index $(\mathrm{GFI})$ of $>0.95$; and root mean square error of approximation (RMSEA) of values less than $0.08(<0.08)$ (Hair et al., 2006).

Table 6 and Table 7 show that the goodness of fit of generated or revised model is better compared to the hypothesized model. This is expected as a hypothesized model is usually strictly confirmatory (Byrne, 2001). The revised model showed a better GFI 0.903 in comparing to the hypothesized model of 0.823 . Furthermore, Root Mean Square Error Approximation shows as well an improved reading of 0.006 for the revised model $\mathrm{n}$ comparing to the hypothesized model of 0.043 .

\subsection{Hypotheses Results}

The explanation of the result will be based on revised model results as it shown in (Table 7 and Figure 3 ). 
Table 7. Direct Impact of Revised Model: Standardized Regression Weights

\begin{tabular}{ccccccccc}
\hline $\mathrm{H}$ & Endogenous & & Exogenous & $\begin{array}{c}\text { Std. } \\
\text { Estimate }\end{array}$ & S.E. & C.R. & P-value & Status \\
\hline H1 & Perceived value & $\leftarrow$ & Tangibility & -0.083 & 0.03 & -0.932 & 0.351 & Not sig \\
H2 & Perceived value & $\leftarrow$ & Reliability & -0.09 & 0.12 & -0.106 & 0.916 & Not sig \\
H3 & Perceived value & $\leftarrow$ & Responsiveness & 0.096 & 0.71 & 0.586 & 0.558 & Not sig \\
H4 & Perceived value & $\leftarrow$ & Assurance & 0.171 & 0.14 & 1.203 & 0.229 & sig \\
H5 & Perceived value & $\leftarrow$ & Empathy & -0.134 & 0.17 & -0.978 & 0.328 & Not sig \\
H6 & Student's satisfaction & $\leftarrow$ & Perceived service & 0.83 & 0.1 & 8.812 & $* * *$ & Sig \\
\hline
\end{tabular}

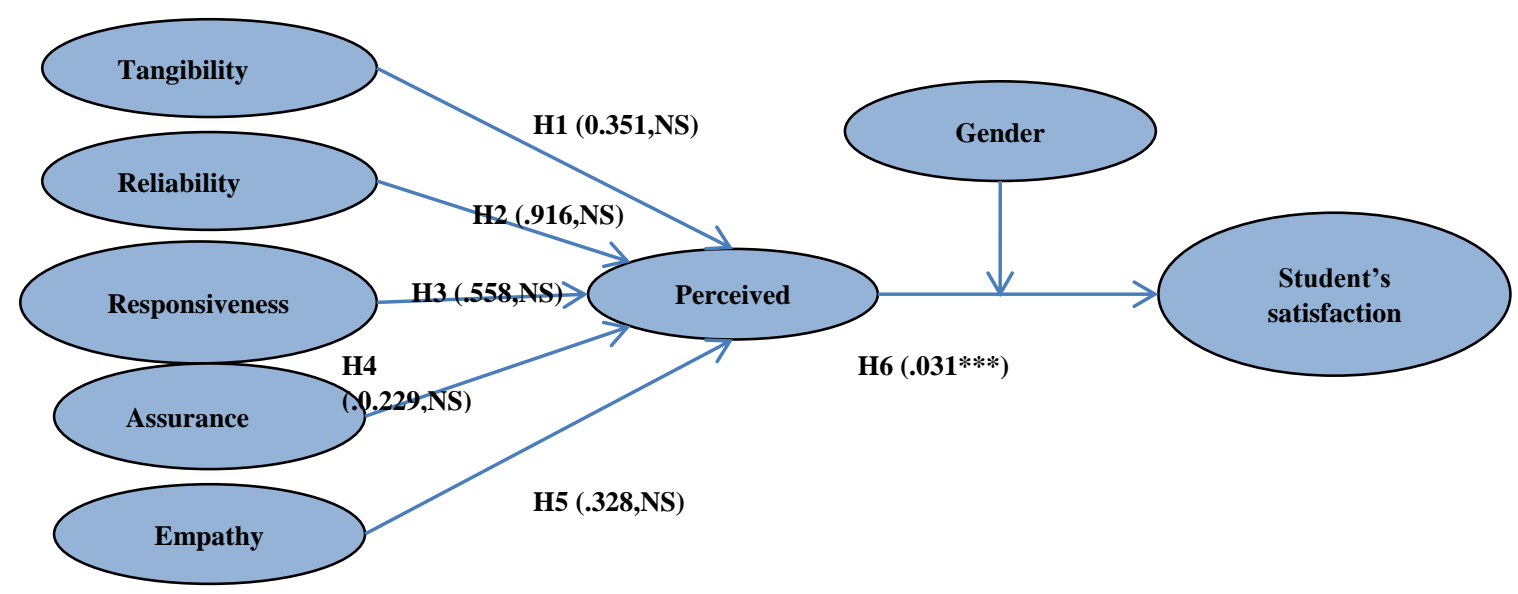

Figure 3. Direct path result of revised model

A significant positive antecedent of customer loyalty has been indicted by the study result with commitment. The perceived value appears to has a significant direct effect on student's satisfaction $(\beta=0.830 ; C R=8.812 ; \mathrm{P}<0.000)$ therefor the $\mathrm{H} 6$ is asserted. On the other hand, the H1, H2, H3, H4, and $\mathrm{H} 5$ fund to have insignificant effect, therefore, they H1, H2, H3, H4, and $\mathrm{H} 5$ are not asserted (insignificant Beta) which led to reject these hypotheses.

As indicated in Table 2, which point out the quantity of variance clarified by the exogenous variables in the revised model. Initially, empathy, reliability, assurance, responsiveness, tangibility explains $5.4 \%$ variance in perceived value. Secondly, perceived value explains $75.8 \%$ variance in student's satisfaction.

\subsection{Mediating Effect Analysis of Revised Model}

The indirect effect estimates to test the mediating effects of Perceived value on the five relationships as hypothesized in hypotheses $\mathrm{H} 7$ to $\mathrm{H} 11$ are displayed in Table 9 and10. The result indicted that, $\mathrm{H} 7$ to H11 are not supported. It is revealed that perceived value does not mediate the relationship between responsiveness, reliability, tangibility, empathy, and assurance with student's satisfaction. There were no significant upsurges of indirect impacts on these relations compared to direct effects.

Table 8. Indirect effect of variables interaction

\begin{tabular}{|c|c|c|c|c|c|c|c|c|}
\hline $\mathrm{H}$ & Exogenous & & Mediated & & Endogenous & $\begin{array}{c}\text { direct Effects } \\
\text { Estimate-No link }\end{array}$ & $\begin{array}{l}\text { direct Effects } \\
\text { Estimate-link }\end{array}$ & $\begin{array}{l}\text { Mediating } \\
\text { Hypothesis }\end{array}$ \\
\hline $\mathrm{H} 7$ & Tangibility & $\rightarrow$ & Perceived value & $\rightarrow$ & $\begin{array}{c}\text { Students } \\
\text { satisfaction }\end{array}$ & $\begin{array}{c}\text { Tan } \quad \text { PS }=-.085 \mathrm{NS} \\
\text { PS } \quad \mathrm{SS}=.83 \mathrm{~S}\end{array}$ & $\begin{array}{c}-.057 \mathrm{NS} \\
.81 \mathrm{~S}\end{array}$ & $\begin{array}{l}\text { Non } \\
\text { mediator }\end{array}$ \\
\hline H8 & Reliability & $\rightarrow$ & Perceived value & $\rightarrow$ & $\begin{array}{c}\text { Students } \\
\text { satisfaction }\end{array}$ & $\begin{array}{c}\text { Rel } \mathrm{PS}=.021 \mathrm{NS} \\
\text { PS } \quad \mathrm{SS}=.83 \mathrm{~S}\end{array}$ & $\begin{array}{c}-.021 \mathrm{NS} \\
.83 \mathrm{~S}\end{array}$ & $\begin{array}{l}\text { Non } \\
\text { mediator }\end{array}$ \\
\hline H9 & Responsiveness & $\rightarrow$ & Perceived value & $\rightarrow$ & $\begin{array}{c}\text { Students } \\
\text { satisfaction }\end{array}$ & $\begin{aligned} \text { Res } & \text { PS }=06 \mathrm{NS} \\
\text { PS } & \mathrm{SS}=.83 \mathrm{~S}\end{aligned}$ & $\begin{array}{c}.030 \mathrm{NS} \\
.82 \mathrm{~S}\end{array}$ & $\begin{array}{l}\text { Non } \\
\text { mediator }\end{array}$ \\
\hline
\end{tabular}




\begin{tabular}{|c|c|c|c|c|c|c|c|c|}
\hline H10 & Assurance & $\rightarrow$ & Perceived value & $\rightarrow$ & $\begin{array}{l}\text { Students } \\
\text { satisfaction }\end{array}$ & $\begin{array}{c}\text { Ass } \quad \mathrm{PS}=.154 \mathrm{NS} \\
\text { PS }\end{array}$ & $\begin{array}{c}.045 \mathrm{NS} \\
.83 \mathrm{~S}\end{array}$ & $\begin{array}{c}\text { Non } \\
\text { mediator }\end{array}$ \\
\hline H11 & Empathy & $\rightarrow$ & Perceived value & $\rightarrow$ & $\begin{array}{c}\text { Students } \\
\text { satisfaction }\end{array}$ & $\begin{array}{c}\text { Emp } \quad \mathrm{PS}=-.031 \mathrm{NS} \\
\text { PS } \quad \mathrm{SS}=.84 \mathrm{~S}\end{array}$ & $\begin{array}{c}.061 \mathrm{NS} \\
.84 \mathrm{~S}\end{array}$ & $\begin{array}{c}\text { Non } \\
\text { mediator }\end{array}$ \\
\hline
\end{tabular}

Table 10. Total effect of mediating variable

\begin{tabular}{|c|c|c|c|c|c|c|c|c|}
\hline $\mathrm{H}$ & Exogenous & & Mediated & & Endogenous & $\begin{array}{l}\text { Direct } \\
\text { Effects }\end{array}$ & $\begin{array}{l}\text { Indirect } \\
\text { Effects }\end{array}$ & $\begin{array}{c}\text { Total } \\
\text { Effect }\end{array}$ \\
\hline $\mathrm{H} 7$ & Tangibility & $\rightarrow$ & $\begin{array}{l}\text { Perceived } \\
\text { value }\end{array}$ & $\rightarrow$ & $\begin{array}{c}\text { Student's } \\
\text { satisfaction }\end{array}$ & -0.134 & -0.111 & -0.245 \\
\hline $\mathrm{H} 8$ & Reliability & $\rightarrow$ & $\begin{array}{l}\text { Perceived } \\
\text { value }\end{array}$ & $\rightarrow$ & $\begin{array}{l}\text { Student's } \\
\text { satisfaction }\end{array}$ & 0.171 & 0.142 & 0.313 \\
\hline H9 & Responsiveness & $\rightarrow$ & $\begin{array}{l}\text { Perceived } \\
\text { value }\end{array}$ & $\rightarrow$ & $\begin{array}{l}\text { Student's } \\
\text { satisfaction }\end{array}$ & 0.096 & 0.079 & 0.175 \\
\hline $\mathrm{H} 10$ & Assurance & $\rightarrow$ & $\begin{array}{l}\text { Perceived } \\
\text { value }\end{array}$ & $\rightarrow$ & $\begin{array}{l}\text { Student's } \\
\text { satisfaction }\end{array}$ & -0.009 & -0.008 & -0.017 \\
\hline H11 & Empathy & $\rightarrow$ & $\begin{array}{l}\text { Perceived } \\
\text { value }\end{array}$ & $\rightarrow$ & $\begin{array}{c}\text { Student's } \\
\text { satisfaction }\end{array}$ & -0.083 & -0.069 & -0.152 \\
\hline
\end{tabular}

Note: Standardized path estimates are reported

\subsection{Overall Comparison Between Structural Models}

By looking on Table 11, it shows a complete image of comparison between the two hypothesized and revised structural models of this study. The hypothesized model produces one significant direct impact and likewise the revised model as well. However, due to un-achievement of $p$-value $(\mathrm{p}<0.05)$ these results could not be generalized. On the other hand, it give the impression that a significant direct effect of perceived value on student's satisfaction presented in (H6), is consistently significant across the two structural models. Alternatively, five direct paths, i.e., the paths from tangibility, reliability, responsiveness, assurance and empathy and student's satisfaction are consistently insignificant across the structural models.

Among the two structural models, revised model achieved the higher squared multiple correlations (SMC) or $\left(\mathrm{R}^{2}\right)$, in which the revised model explains $75.8 \%$ variance in Students satisfaction and $5.4 \%$ variance in perceived value. The hypothesized model only explains $69.8 \%$ variance in Students satisfaction and $2.9 \%$ variance in perceived value.

Table 11. Comparison between hypothesized model and generated model

\begin{tabular}{|c|c|c|c|c|c|c|c|c|c|}
\hline \multirow[b]{2}{*}{$\mathrm{H}$} & \multirow[b]{2}{*}{ Exogenous } & \multirow[b]{2}{*}{ Mediation } & \multirow[b]{2}{*}{ Endogenous } & \multicolumn{3}{|c|}{ Hypothesized Model } & \multicolumn{3}{|c|}{ Generated Model } \\
\hline & & & & $\begin{array}{c}\text { Std. } \\
\text { Estimate }\end{array}$ & $\mathrm{P}$ & $\begin{array}{c}\text { Hypothesis } \\
\text { Status }\end{array}$ & $\begin{array}{c}\text { Std. } \\
\text { Estimate }\end{array}$ & $\mathrm{P}$ & $\begin{array}{c}\text { Hypothesis } \\
\text { Status }\end{array}$ \\
\hline H1 & Tangibility & & Perceived Value & -0.055 & 0.537 & Rejected & -0.058 & 0.351 & Rejected \\
\hline $\mathrm{H} 2$ & Reliability & & Perceived Value & -0.008 & 0.936 & Rejected & -0.17 & 0.916 & Rejected \\
\hline H3 & Responsiveness & & Perceived Value & 0.08 & 0.472 & Rejected & 0.166 & 0.558 & Rejected \\
\hline $\mathrm{H} 4$ & Assurance & & Perceived Value & 0.343 & 0.121 & Rejected & 0.09 & 0.229 & Asserted \\
\hline H5 & Empathy & & Perceived Value & -0.331 & 0.124 & Rejected & 0.001 & -0.328 & Rejected \\
\hline H6 & $\begin{array}{l}\text { Perceived } \\
\text { service }\end{array}$ & & $\begin{array}{c}\text { Students } \\
\text { satisfaction }\end{array}$ & 0.869 & $* * *$ & Asserted & 0.83 & $* * *$ & Asserted \\
\hline $\mathrm{H} 7$ & Tangibility & $\begin{array}{l}\text { Perceived } \\
\text { Value }\end{array}$ & $\begin{array}{l}\text { Students } \\
\text { satisfaction }\end{array}$ & - & - & - & -0.083 & 0.105 & $\begin{array}{c}\text { Not } \\
\text { mediating }\end{array}$ \\
\hline
\end{tabular}




\begin{tabular}{|c|c|c|c|c|c|c|c|c|c|}
\hline H8 & Reliability & $\begin{array}{l}\text { Perceived } \\
\text { Value }\end{array}$ & $\begin{array}{c}\text { Students } \\
\text { satisfaction }\end{array}$ & - & - & - & -0.09 & 0.285 & $\begin{array}{c}\text { Not } \\
\text { mediating }\end{array}$ \\
\hline H9 & Responsiveness & $\begin{array}{l}\text { Perceived } \\
\text { Value }\end{array}$ & $\begin{array}{c}\text { Students } \\
\text { satisfaction }\end{array}$ & - & - & - & 0.096 & 0.457 & $\begin{array}{c}\text { Not } \\
\text { mediating }\end{array}$ \\
\hline $\mathrm{H} 10$ & Assurance & $\begin{array}{l}\text { Perceived } \\
\text { Value }\end{array}$ & $\begin{array}{c}\text { Students } \\
\text { satisfaction }\end{array}$ & - & - & - & 0.171 & 0.302 & $\begin{array}{c}\text { Not } \\
\text { mediating }\end{array}$ \\
\hline H11 & Empathy & $\begin{array}{l}\text { Perceived } \\
\text { Value }\end{array}$ & $\begin{array}{c}\text { Students } \\
\text { satisfaction }\end{array}$ & - & - & - & -0.134 & 0.285 & $\begin{array}{c}\text { Not } \\
\text { mediating }\end{array}$ \\
\hline \multicolumn{10}{|c|}{ Goodness of Fit Index: } \\
\hline \multicolumn{4}{|c|}{ Chi-Square } & \multicolumn{3}{|c|}{747.538} & \multicolumn{3}{|c|}{260.59} \\
\hline \multicolumn{4}{|c|}{ Chi-squre change } & & & & \multicolumn{3}{|c|}{486.948} \\
\hline \multicolumn{4}{|c|}{ Df } & \multicolumn{3}{|c|}{512} & \multicolumn{3}{|c|}{259} \\
\hline \multicolumn{4}{|c|}{ Df change } & & & & \multicolumn{3}{|c|}{253} \\
\hline \multicolumn{4}{|c|}{ Ratio } & \multicolumn{3}{|c|}{1.46} & \multicolumn{3}{|c|}{1.006} \\
\hline \multicolumn{4}{|c|}{ P Value } & \multicolumn{3}{|c|}{0} & \multicolumn{3}{|c|}{0.454} \\
\hline \multicolumn{4}{|c|}{ GFI } & \multicolumn{3}{|c|}{0.823} & \multicolumn{3}{|c|}{0.903} \\
\hline \multicolumn{4}{|c|}{ RMSEA } & \multicolumn{3}{|c|}{0.048} & \multicolumn{3}{|c|}{0.006} \\
\hline \multicolumn{10}{|c|}{ Squared Multiple Correlation (SMC): } \\
\hline \multicolumn{4}{|c|}{ Perceived value } & \multicolumn{3}{|c|}{$2.90 \%$} & \multicolumn{3}{|c|}{$5.40 \%$} \\
\hline \multicolumn{4}{|c|}{ Students satisfaction } & \multicolumn{3}{|c|}{$69.80 \%$} & \multicolumn{3}{|c|}{$75.80 \%$} \\
\hline
\end{tabular}

\section{Conclusions}

The University of Medical Sciences and Technology (UMST) began as a private, non-profit making educational institution, in Khartoum, Sudan, which was established in 1996 to serve the educational needs of Sudanese, African and Arab students. In a few years, UMST has expanded to ten faculties, namely, Medicine, Pharmacy, Medical Laboratory Sciences, Dentistry, Dental Technology, Nursing, Computer Sciences, Administrative \& Financial Sciences Biomedical Engineering and Anaesthetic Sciences. Officially accredited and recognized by the Ministry of Higher Education and Scientific Research, Sudan. UMST offers courses and programs leading to officially recognized higher education degrees such as bachelor degrees, master degrees in several areas of study. It also provides several academic and non-academic facilities and services to students including a library, housing, sports facilities and activities, financial aids and scholarships, as well as administrative services

The purpose of this paper was to examine the effects of the Perceived mediating value on the relationship between the Service Quality Dimensions (Tangibility, Reliability, Responsiveness, Assurance, and Empathy) and Students' Satisfaction in UMST Hostel Accommodation. The research shows Perceived value has a significant direct impact on student's satisfaction Hostel Accommodation. It shows Perceived value does not mediate the relationship between tangibility, reliability, responsiveness, assurance and empathy and student's satisfaction Hostel Accommodation. There are no significant increases of indirect effects for these relationships compared to direct impacts. These findings can be generalized to all Sudanese educational providers because there are so many variables other than (tangibility, reliability, responsiveness, assurance, and empathy) may contribute to student's satisfaction not excluded in this study.

Also the ownership of Sudanese educational providers ranging from public universities, private universities and private but non-profit making universities.

This opens an area of conducting future researchers using other variables not included in addition to considering different types of ownership of Sudanese educational providers.

\section{References}

Alridge, D. P., \& Rowley, L. L. (2001). WEB Du Bois: The Fight for Equality and the American Century, 1919-1963.

Bagozzi, R. P., \& Yi, Y. (1988). On the evaluation of structural equation models. Journal of the Academy 
Marketing Science, 16, 74-94. https://doi.org/10.1007/BF02723327

Beerli Palacio, A., Díaz Meneses, G., \& Pérez Pérez, P. J. (2002). The configuration of the university image and its relationship with the satisfaction of students. Journal of Educational Administration, 40(5), 486-505. https://doi.org/10.1108/09578230210440311

Brian Hwarng, H., \& Teo, C. (2001). Translating customers' voices into operations requirements-A QFD application in higher education. International Journal of Quality \& Reliability Management, 18(2), 195-226. https://doi.org/10.1108/02656710110379075

Byrne, B. M. (2001). Structural equaltion modeling with AMOS- Basic concepts, applications and programming. New Jersey: Lawrence Erlbaum Associates.

Carey, K., Cambiano, R. L., \& De Vore, J. B. (2002). Student to faculty satisfaction at a Midwestern university in the United States. In The 25th HERSDA Annual Conference. Retrieved July 29, 2018, from http://www.sciepub.com/reference/199889

Fornell, C., \& Larcker, D. (1981). Evaluating structural equation model with unobservable variables and measurement error. Journal of Marketing Research, 18(1), 39-50. https://doi.org/10.2307/3151312

Fornell, C. (1992). A national customer satisfaction barometer: the Swedish experience. Journal of Marketing, 55, (January). https://doi.org/10.2307/1252129

Fornell, C., \& Larcker, D. F. (1981). Structural equation models with unobservable variables and measurement error: Algebra and statistics. Journal of marketing research, 382-388. https://doi.org/10.2307/3150980

Grönroos, C. (1984). A service quality model and its marketing implications. European Journal of Marketing, 18(4), 36-44. https://doi.org/10.1108/EUM0000000004784

Hair, J. F., Black, W. C., Babin, B. J., Anderson, R. E., \& Tatham, R. L. (2006). Multivariate data analysis (Vol. 6).

Hair Jr, J. F., Sarstedt, M., Hopkins, L., \& G. Kuppelwieser, V. (2014). Partial least squares structural equation modeling (PLS-SEM) An emerging tool in business research. European Business Review, 26(2), 106-121. https://doi.org/10.1108/EBR-10-2013-0128

Hill, F. M. (1995). Managing service quality in higher education: The role of the student as primary consumer. Quality assurance in education, 3(3), 10-21. https://doi.org/10.1108/09684889510093497

Krejcie, R. V., \& Morgan, D. W. (1970). Activities. The NEA Research Bulletin, 38, 607-610.

Kanji, G. K., Tambi, A. M. B. A., \& Wallace, W. (1999). A comparative study of quality practices in higher education institutions in the US and Malaysia. Total Quality Management, 10(3), 357-371. https://doi.org/10.1080/0954412997884

Kothari, R., Buddhi, D., \& Sawhney, R. L. (2008). Comparison of environmental and economic aspects of various hydrogen production methods. Renewable and Sustainable Energy Reviews, 12(2), 553-563. https://doi.org/10.1016/j.rser.2006.07.012

Kothari, R., Buddhi, D., \& Sawhney, R. L. (2008). Comparison of environmental and economic aspects of various hydrogen production methods. Renewable and Sustainable Energy Reviews, 12(2), 553-563.

Kotler, P., \& Clarke, R. N. (1987). Marketing for Health Organization. Prentic-Hall Inc.

Krejcie, R. V., \& Morgan, D. W. (1970). Determining sample size for research activities. Educational and psychological measurement, 30(3), 607-610. https://doi.org/10.1177/001316447003000308

Lassar, W. M., Manolis, C., \& Winsor, R. D. (2000). Service quality perspectives and satisfaction in private banking. Journal of Services Marketing, 14(3), 244-271. https://doi.org/10.1108/08876040010327248

Oldfield, B. M., \& Baron, S. (2000). Student perceptions of service quality in a UK university business and management faculty. Quality Assurance in Education, 8(2), 85-95. https://doi.org/10.1108/09684880010325600

Omar, K. M. (2016). The Moderating Roles of Selling Skills and Knowledge on the Customer Satisfaction and the Organization Performance. American Journal of Economics, 6(3), 158-170. https://doi:10.5923/j.economics.20160603.02

Omar, K. M., Mat, N. K. N., Imhemed, G. A., \& Ali, F. M. A. (2012). The direct effects of halal product actual purchase antecedents among the international Muslim consumers. American Journal of Economics, 2(4), 
87-92. https://doi.org/10.5923/j.economics.20120001.20

Parasuraman, A., Zeithaml, V. A., \& Berry, L. L. (1985). A conceptual model of service quality and its implications for future research. The Journal of Marketing, 41-50. https://doi.org/10.2307/1251430

Sekaran, U., \& Leong, F. T. (1992). Womanpower: Managing in times of demographic turbulence. Sage Pubns.

Tabachnik \& Fidell (2007). Development of a brief measure of career development influences based on the system. Australian Journal of Career Development, 6(3 Spring), 4-22.

Zammuto, R. F., Keaveney, S. M., \& O'Connor, E. J. (1996). Rethinking student services: Assessing and improving service quality. Journal of Marketing for Higher Education, 7(1), 45-70. https://doi.org/10.1300/J050v07n01_05

Zeithaml, V. A., Berry, L. L., \& Parasuraman, A. (1996). The behavioral consequences of service quality. The Journal of Marketing, 31-46. https://doi.org/10.2307/1251929

\section{Copyrights}

Copyright for this article is retained by the author(s), with first publication rights granted to the journal.

This is an open-access article distributed under the terms and conditions of the Creative Commons Attribution license (http://creativecommons.org/licenses/by/4.0/). 